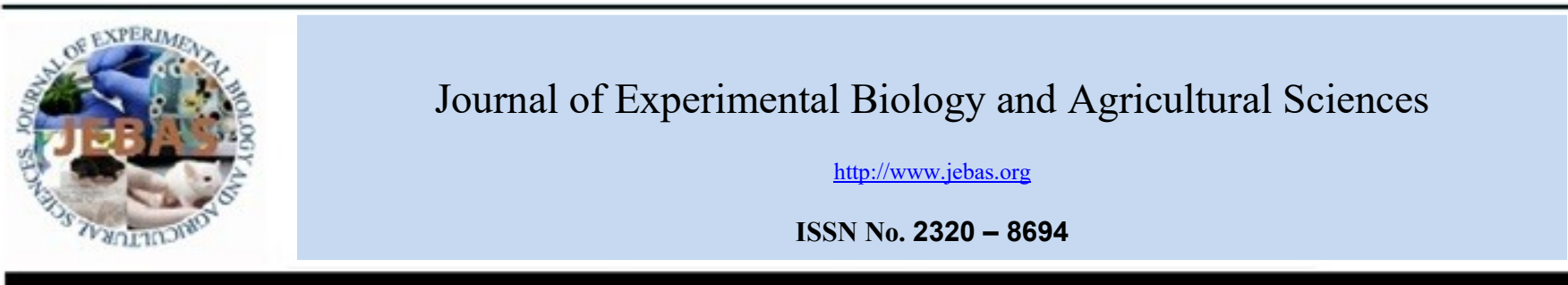

\title{
Colletotrichum fusiforme JAYAWARDENA, BHAT, N.TANGTHIR, K.D.HYDE, A NEW FUNGAL RECORD FROM THE INDIAN SUBCONTINENT
}

\section{Pandey Atul Kumar, Rai Akhila Nand}

Mycology and Plant Pathology Laboratory, Department of Botany, Dr Harisingh Gour University, Sagar M.P. India, 47000

Received - May 11, 2020; Revision - July 08, 2020; Accepted - August 16, 2020

Available Online - August 25, 2020

DOI: http://dx.doi.org/10.18006/2020.8(4).500.507

\section{KEYWORDS}

Colletotrichum fusiforme

ITS sequence

Morphological analysis

Molecular analysis

Srilankan Chest wood plant

MEGA-X

\begin{abstract}
This communication deals with the description and illustration of a new fungal record Colletotrichum fusiforme Jayawardena, Bhat, N.Tangthir, K.D.Hyde. The fungus was isolated from the leaves of a medicinally and aesthetically important Srilankan Chest Wood plant (Mesua ferrea L., Family Calophyllaceae), during the survey of the Botanic garden of Dr Harisingh Gour University, Sagar, Madhya Pradesh, India. The study was carried out by the conventional technique (morpho-mycotaxonomy) and it was confirmed by ITS sequence analysis, the phylogenetic relationships are made with MEGA-X.
\end{abstract}

* Corresponding author

E-mail: atulkpandey34337@gmail.com (Pandey Atul Kumar)

Peer review under responsibility of Journal of Experimental Biology and Agricultural Sciences.

Production and Hosting by Horizon Publisher India [HPI] (http://www.horizonpublisherindia.in/).

All rights reserved.
All the articles published by Journal of Experimental Biology and Agricultural Sciences are licensed under a Creative Commons Attribution-NonCommercial 4.0 International License Based on a work at www.jebas.org.

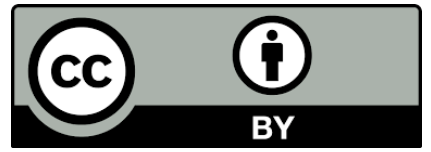




\section{Introduction}

Mesua ferrea L., Family - Calophyllaceae, is a very important medicinal plant. It is a medium-sized evergreen plant distributed in almost all Asian countries like Burma, Cambodia, Indonesia, Malaysia, Srilanka, Myanmar, Nepal, Philippines, Sumatra and Thailand (Asif et al., 2017). M. ferrea is widely used as an antipyretic, antimicrobial, anticancer, carminative, cardiotonic, diuretic and expectorant (Rahman et al., 2008; Chahar et al., 2012). In India also, M. ferrea is widely used in the number of ayurvedic medicines for the treatment of many diseases like bleeding piles, cough, cardiovascular disorder, dysentery, excessive thirst, scabies (Joseph et al., 2010; Lim, 2012). Presence of phytochemicals like xanthones, terpenoids and sterol justify its medicinal properties (Keawsa-ard et al., 2015).

M. ferrea tree is threatened by many fungal pathogens among these foliar pathogens are also well reported. Presence of the fungal genus Colletotrichum sp. was also reported from the tree (Sunkar et al., 2017). Genus Colletotrichum was first reported by Tode (1790) as the genus Vermicularia, while its current name was established by Corda (1831) for C. lineola (Cannon et al., 2012). This genus is considered as the plant pathogenic genus which causes diseases in various economically important plants (Jayawardena et al., 2016). According to Dean et al. (2012), its host range varies from trees to the small grasses. The Colletotrichum sp. exhibits various natures such as endophytic, parasitic, saprophytic lifestyles (Kumar, 2014). The inoculums of Colletotrichum are disseminated through wind or rain from one to another host and for the extensive growth and higher degree of infection; it requires warm and humid conditions (Purkayastha \& Sen Gupta, 1973; Farr et al., 2006; Kumar, 2014). During the intensive survey of Dr Harisingh Gour University, Sagar botanical garden vegetation, conspicuous pinhead dots was reported on the leaves of $M$. ferrea. Aim of this investigation was to identify fungal pathogens associated with these pinheads dots.

\section{Materials and Methods}

\subsection{Sample collection:}

The weather of Sagar M.P. is highly humid and rainy from July to November which favours the growth and development of various fungal pathogens (Figure 1). The infected leaves of $M$. ferrea plants were collected in new unused polythene bags from the botanical garden of Dr Harisingh Gour University, Sagar. Each polythene bag was marked by paper tag on which descriptions of the host plant, local name, place, collection date, symptoms and serial number were noted (Mall \& Kumar, 2014; Sabeena et al., 2018). After returning from the field visit, sample specimens were kept between blotters for proper pressing, this absorbs moisture which helps in avoiding saprophytic cross contaminators (Sabeena et al., 2018).

\subsection{Isolation of fungi \& Morphological characterization}

The collected samples were processed according to the standardized procedure (Savile, 1962; Hawskworth 1974). The detailed and critical morphological identification was carried out with the help of Scanning Electron Microscope (NOVA NANOSEM 450). For this, specimens were dehydrated and coated

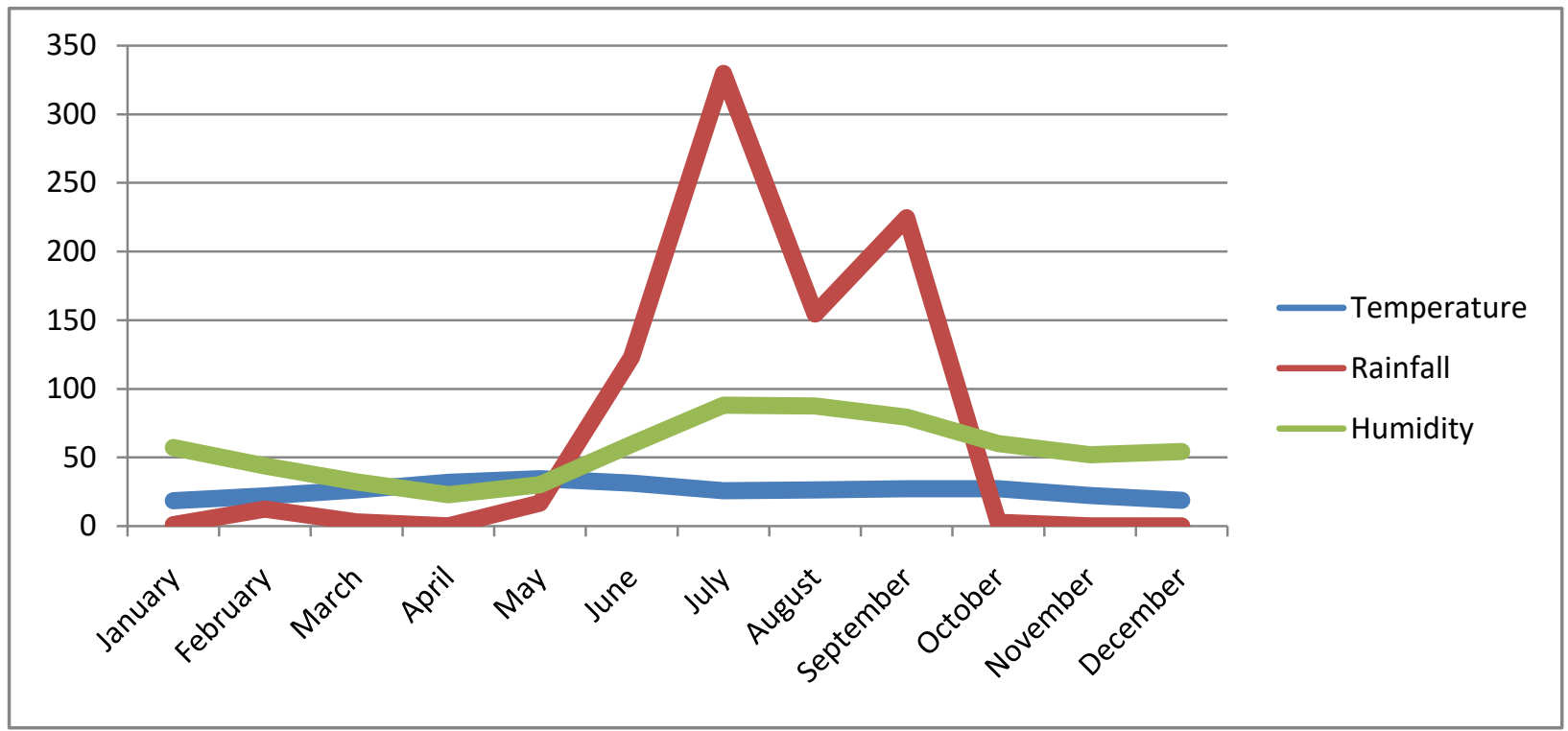

Figure 1 showing the temperature, rainfall, and humidity variances throughout the year 2017

Journal of Experimental Biology and Agricultural Sciences http://www.jebas.org 
with conducting material (Gold) to prevent charge built from electron beam (Hall \& Hawes, 1991). The SEM microphotograph revealed the unseen structures of the fungus and their measurements. With the help of standard monographs of Coelomycetes (Sutton, 1980) and some other important available literature, the comparison list was prepared (Table 2). The Holotype of the specimen has been deposited for accession number in Ajrekar Mycological Herbarium (AMH) of Agharkar Research Institute (ARI), Pune, Maharastra India.

\subsection{Molecular characterization}

For molecular studies, the fungal organism was isolated from the infected leaf of $M$. ferrea and aseptically transferred to the PDA media. The pathogen grows prolifically on PDA media under a controlled environment at $25-28^{\circ} \mathrm{C}$ in the incubator. Vigorous growth was obtained after the fifth day of inoculation, by subsequent subculture process, pure culture of the desired isolate obtains. The pure culture has also been deposited to the National fungal culture collection of India (NFCCI), Agharkar Research Institute (A.R.I.) Pune, Maharastra (India) for the accession. DNA from the pure culture was isolated by using the CTAB extraction buffer (Carlier et al., 1996). This isolated DNA was used for the sequencing and distinguishes differences between various Colletotrichum species by Mills et al. (1992) method. The variation in the sequence of the ITS1 region of rDNA used for the detection of polymorphisms in the same region between various strains of Colletotrichum (Sreenivasaprasad et al., 1992). ITS4 \& ITS5 universal primers (White et al., 1990) were used to amplify the ITS gene in sequencing PCR ABI3100 automated DNA sequencer with $\mathrm{ABI}-\mathrm{BigDye}{ }^{\circledR}$ Terminator 3.1 Cycle sequencing kit. The sequence of the Universal ITS primers used in the current study are:

\section{ITS 4 (5'TCCTCCGCTTATTGATATGC3') (Forward primer)}

\section{ITS 5 (5'GGAAGTAAAAGTCGTAACAAGG3') (Reverse primer)}

To render the similarities between different species the DNA sequence BLAST (Basic Local Alignment Search Tool) is done on the NCBI website (https://blast.ncbi.nlm.nih.gov). The DNA sequence was also deposited in the NCBI database and obtain genebank accession no. MH352480. The DNA sequences of the other similar species were downloaded and utilized for making a phylogenetic tree by using MEGA-X. Host records were checked for the novelty of the taxa by using the Index Fungorum website (http://www.indexfungorum.org) and the USDA website (https://nt.arsgrin.gov/fungaldatabases).

\subsection{Phylogenetic analysis}

For the conversion of the raw DNA sequence into the fasta format EMBOSS programs-EMBL-EBI online software is used, DNA Sequence (Fasta format) is used for the NCBI BLAST (Basic Local Alignment Search Tool). NCBI BLAST hits provide the sequence similarity percentage, query coverage, E-value (Table 3 ) in between the sequences already submitted by the different workers, with these data, it is easier to identify the isolate at the species level, it also provides the facility to download the most related sequences for making the phylogenetic tree by aligning them using Muscle (Edgar, 2004) in MAGA X (Hall, 2013) software, which gives the clear cut estimation of the relationship between the taxa (Sequences) (Nei \& Kumar, 2000; Felsenstein, 2004; Hall, 2011). Now the test of phylogeny was done by the bootstrap method using the maximum likelihood statistical method, with 1000 replications.

\subsection{Pathogenicity test}

The conidial suspension is spread over the artificially damaged $M$. ferrea leaves and keeps in incubation at room temperature $\left(25^{\circ} \mathrm{C}-\right.$ $28^{\circ} \mathrm{C}$ ) for the proper spreading of the fungal infection. After 72 hours of inoculation, fungal infections start appearing over the leaf surface same as obtained during the investigation and at the end of the seventh-day ambient infection observed. This test was applied in triplet sets in which the optimum temperature varied (Table 1)

\section{Results}

\subsection{Morphotaxonomic Identification:}

Leaf spots are amphigenous, irregular, starts from the acute apex of the leaf and further extending back (Figure 2). The colony is epiphyllous with fine pinhead dots, dark brown to dark black with internal mycelium. Conidiomata are acervular, cuticular, dehiscence irregular, $37.50-75 \times 22.5-50 \mu \mathrm{m}$. Sclerotia are indistinct. Setae are present and arise from the base of conidiomata, abundant, small to long, straight to flexuous, base

Table 1 showing growth variations at the different temperature range

\begin{tabular}{|lll|}
\hline Set & Temperature variance & Growth visualization \\
\hline Set 1 & $22^{\circ} \mathrm{C}-25^{\circ} \mathrm{C}$ & Little to moderate growth observed \\
\hline Set 2 & $25^{0} \mathrm{C}-28^{0} \mathrm{C}$ & Ambient growth observed \\
\hline Set 3 & $28^{\circ} \mathrm{C}-31^{\circ} \mathrm{C}$ & Initially growth increases but later on it starts declining \\
\hline
\end{tabular}

Journal of Experimental Biology and Agricultural Sciences

http://www.jebas.org 
Table 2 Comparison of $C$. fusiforme with allied taxa

\begin{tabular}{|c|c|c|c|c|}
\hline Character & Colony & Appressoria & Conidia & Setae \\
\hline $\begin{array}{l}\text { C. falcatum } \\
\text { Went } \\
\text { (Sutton 1980) }\end{array}$ & $\begin{array}{l}\text { Greyish with sparse aerial } \\
\text { mycelium and small dense } \\
\text { felty patches, sclerotia } \\
\text { absent }\end{array}$ & $\begin{array}{l}\text { Appressoria sparse medium } \\
\text { brown clavate or circular, edge } \\
\text { entire } 12.5-14.45 \times 9.5- \\
12 \mu \mathrm{m}\end{array}$ & $\begin{array}{l}\text { Conidia falcate, fusiform, } \\
\text { apices obtuse, } \\
15.5-26.5 \times 4-5 \mu \mathrm{m}\end{array}$ & Setae sparse \\
\hline $\begin{array}{l}\text { C. gloeosperiodis } \\
\text { Penz. } \\
\text { (Sutton 1980) }\end{array}$ & $\begin{array}{l}\text { Variable in shape, sclerotia } \\
\text { occasionally present }\end{array}$ & $\begin{array}{l}\text { Appressoria are } 6-20 \times 4-20 \\
\mu \mathrm{m}, \quad \text { Clavate or irregular, } \\
\text { sometimes becoming complex }\end{array}$ & $\begin{array}{l}\text { Conidia are straight, obtuse } \\
\text { apex, } 9-24 \times 3-4.5 \mu \mathrm{m}\end{array}$ & Setae present \\
\hline $\begin{array}{l}\text { C. lini } \\
\text { (Westerdijk) } \\
\text { Tochinai } \\
\text { (Sutton 1980) }\end{array}$ & $\begin{array}{l}\text { Colony slow-growing dark } \\
\text { brown to black, dendroid, } \\
\text { aggregations of dark hyphae } \\
\text { sclerotia absent }\end{array}$ & $\begin{array}{l}\text { Appressoria moderately } \\
\text { abundant medium brown, long } \\
\text { clavate irregular } \\
10-13.5 \times 6.5-13.5 \mu \mathrm{m}\end{array}$ & $\begin{array}{l}\text { Conidia falcate but not } \\
\text { strongly Apices obtuse, often } \\
\text { guttulate } \\
16-19 \times 3-4.5 \mu \mathrm{m}\end{array}$ & Setae abundant \\
\hline $\begin{array}{l}\text { C. capsici } \\
\text { (Syd.) Butl. \& } \\
\text { Bisby } \\
\text { (Sutton 1980) }\end{array}$ & $\begin{array}{l}\text { Dense colony, whitish to } \\
\text { dark grey, aerial mycelium, } \\
\text { sclerotia absent }\end{array}$ & $\begin{array}{l}\text { Appressoria abundant, medium } \\
\text { brown, clavate to circular edge } \\
\text { usually entire, } 9-14 \times 6.5- \\
11.5 \mu \mathrm{m}\end{array}$ & $\begin{array}{l}\text { Conidia falcate, fusiform, } \\
\text { apices acute } \\
18-23 \times 3.5-4 \mu \mathrm{m}\end{array}$ & Setae abundant \\
\hline $\begin{array}{l}\text { C. dematium } \\
\text { (Pers. Ex Fr.) } \\
\text { Grove } \\
\text { (Sutton 1980) }\end{array}$ & $\begin{array}{l}\text { Colonies extremely variable, } \\
\text { white to pale grey, sclerotia } \\
\text { abundant black, conical }\end{array}$ & $\begin{array}{l}\text { Appressoia abundant, medium } \\
\text { brown, clavate to circular, edge } \\
\text { usually entire } \\
8-11.5 \times 6.5-8.2 \mu \mathrm{m}\end{array}$ & $\begin{array}{l}\text { Conidia falcate fusiform, } \\
\text { apices acute, } 19.5-24 \times 2-2.5 \\
(-3.5) \mu \mathrm{m}\end{array}$ & Setae abundant \\
\hline $\begin{array}{l}\text { C. truncatum } \\
\text { (Schw.) Andrus } \\
\text { \& Moore } \\
\text { (Sutton 1980) }\end{array}$ & $\begin{array}{l}\text { Colonies dark brown to } \\
\text { black, sclerotia abundant }\end{array}$ & $\begin{array}{l}\text { Appressoria abundant, clevate } \\
\text { or circular, sometimes } \\
\text { irregular, } 11-16 \times 8-9.5 \mu \mathrm{m}\end{array}$ & $\begin{array}{l}\text { Conidia falcate, apices obtuse, } \\
\text { guttulate, } 15.5-24 \times 3.5-4 \\
\mu \mathrm{m}\end{array}$ & Setae abundant \\
\hline $\begin{array}{l}\text { C. fusiforme } \\
\text { Jayawardena, } \\
\text { Bhat, N.Tangthir, } \\
\text { K.D.Hyde } \\
\text { (Ariyawansa et } \\
\text { al., 2015) }\end{array}$ & - & $\begin{array}{l}\text { Appressoria solitary to } \\
\text { aggregated in short-chain, oval } \\
\text { medium to dark brown, } \\
\text { smooth-walled, } 6-11 \times 3-4 \\
\mu \mathrm{m}\end{array}$ & $\begin{array}{l}\text { Conidia, hyaline, fusiform, } \\
\text { aseptate, base rounded, and } \\
\text { truncate with slightly acute } \\
\text { apex, guttulate, smooth- } \\
\text { walled or verruculose, } 34-44 \\
\mu \mathrm{m}\end{array}$ & $\begin{array}{l}\text { Setae abundant, dark } \\
\text { brown to medium } \\
\text { brown, smooth-walled } 1 \\
-4 \text { septate, } 95-225 \mu \mathrm{m} \\
\text { long, base cylindrical, } \\
\text { conical, with slightly } \\
\text { inflated, } 3-5 \mu \mathrm{m} \text {, acute } \\
\text { apex. }\end{array}$ \\
\hline $\begin{array}{l}\text { Colletotrichum } \\
\text { fusiforme on } M . \\
\text { ferrea } \mathrm{L} \text {. }\end{array}$ & $\begin{array}{l}\text { Colonies epiphyllous, dense } \\
\text { brown to black, sclerotia } \\
\text { absent }\end{array}$ & - & $\begin{array}{l}\text { Conidia hyaline, single-celled } \\
\text { (aseptate), smooth, straight to } \\
\text { falcate, acute to obtuse at both } \\
\text { ends, } 12.5- \\
35 \times 2.5-5.0 \mu \mathrm{m}\end{array}$ & $\begin{array}{l}\text { Setae arise from the base } \\
\text { of acervulus, small to } \\
\text { long, straight to } \\
\text { flexuous, swollen at the } \\
\text { base, tapering apex, dark } \\
\text { brown to black, aseptate, } \\
25-175 \times 2.5-7.5 \mu \mathrm{m}\end{array}$ \\
\hline
\end{tabular}

swollen, tapering apex, dark brown to black, aseptate, $25-175 \mathrm{x}$ $2.5-7.5 \mu \mathrm{m}$. Conidiophores are mostly indistinct, $8.7-16.43 \mu \mathrm{m}$ in size in SEM imaging (Figure 4). Condiogenous cells are enteroblastic, phialidic, and the average size is $1.411 \mu \mathrm{m}$ in SEM images, hyaline, determinate. Conidia are hyaline, single-celled (aseptate), smooth, and straight to falcate acute at both ends with 12.5 - $25 \times 2.5-5.0 \mu \mathrm{m}$ size (Figure 3). The comparison with the allied taxa is shown in table 2. Based on the above-said characteristics, morpho-taxonomic identification suggested that isolated fungal species is Colletotrichum fusiforme Jayawardena, Bhat, N. Tangthir, K.D.Hyde, Holotype, AMH - 9939.

\subsection{Culture characteristics}

On PDA colony becomes $30-45 \mathrm{~mm}$ in size in 10 days at $25^{\circ} \mathrm{C}$. Colony is dark black in the centre while dark olivaceous green colony with the wavy edges. Reverse view of the colony is olivaceous green to black, concentric (Figure 5). On the behalf of colony characteristics and morphological characteristics isolated $\boldsymbol{C}$. fusiforme compared with the allied taxa and this comparison is given in table 2.

\subsection{Molecular Identification:}

NCBI BLAST analysis of top five BLAST hits indicates that the isolated DNA sequence show 100 per cent query coverage and identity with the Colletotrichum fusiforme, Fungal endophyte isolate LIES529, Colletotrichum sp. WF134, Colletotrichum sp. WF115, Colletotrichum sp. VNCF2 (Table 3). The evolutionary history was inferred by using the maximum likelihood method and the Tamura-Nei model (Tamura \& Nei 1993). The bootstrap consensus tree inferred from 1000 replicates is taken to represent the evolutionary history of the analyzed taxa (Felsenstein, 1985). Branches corresponding to partitions reproduced in less than $50 \%$ 


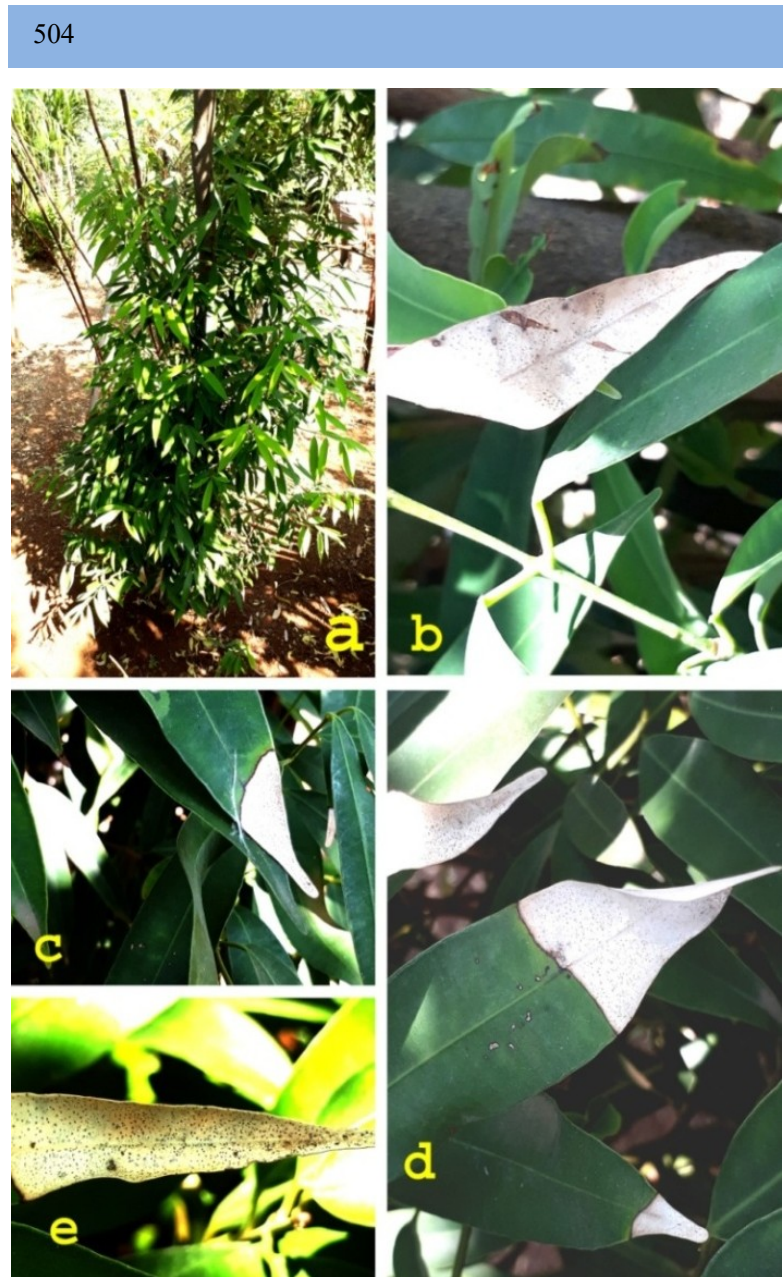

Figure 2 Symptoms of Colletrotrichum fusiforme Jayawardena, Bhat, N.Tangthir, K.D.Hyde on M. ferrea L. (Holotype, AMH 9939), a - Infected host plant, b-e - infection spots along with colonies on different leaves.

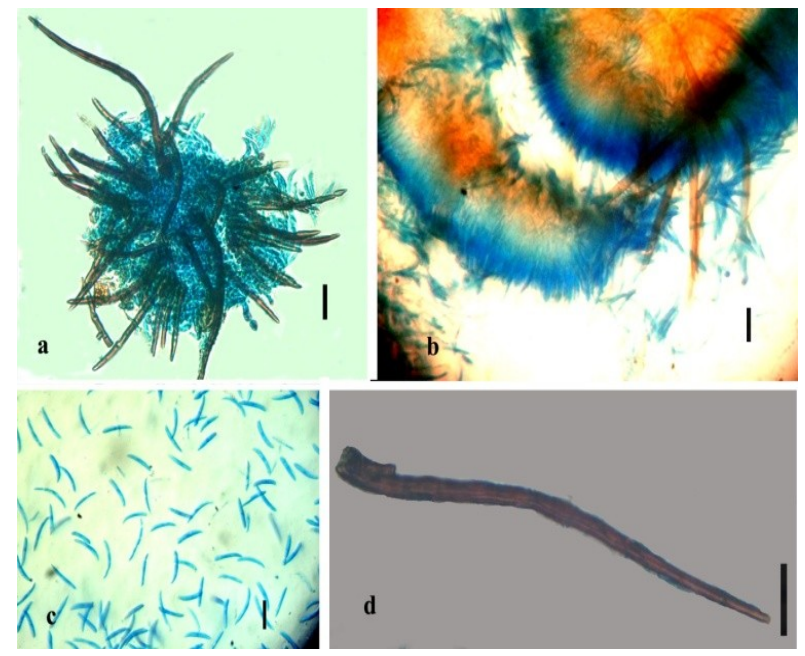

Figure 3 showing the morphology of acervulus, conidia and setae, $\mathrm{a}-\mathrm{b}$ - acervulus with abundant setae, $\mathrm{c}$ - numerous conidia, $\mathrm{d}$ - seta (Scale Bars a-d - $20 \mu \mathrm{m}$ )
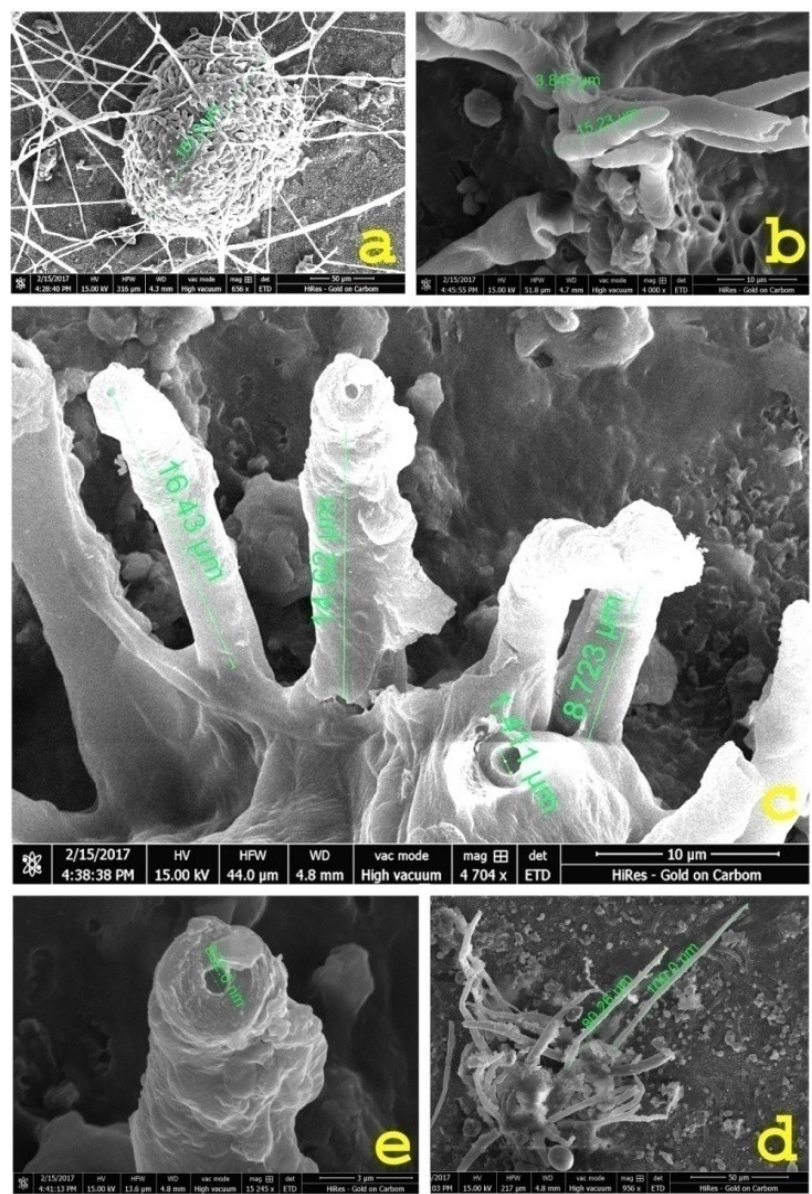

Figure 4 SEM visualization of Colletrotrichum fusiforme Jayawardena, Bhat, N.Tangthir, K.D.Hyde on M. ferrea (Holotype, AMH - 9939), a colony over leaf surface (Scale $=50 \mu \mathrm{m}), \mathrm{b}$ - setae, $\mathrm{c}$ - conidiophores, $\mathrm{d}$ - acervulus with numerous setae, $\mathrm{e}-$ conidiogenous cell.

bootstrap replicates are collapsed. The percentage of replicate trees in which the associated taxa clustered together in the bootstrap test (1000 replicates) is shown next to the branches (Felsenstein, 1985). Initial tree(s) for the heuristic search were obtained automatically by applying Neighbor-Join and BioNJ algorithms to a matrix of pair wise distances estimated using the Maximum Composite Likelihood (MCL) approach and then selecting the topology with superior log likelihood value. This analysis involved 6 nucleotide sequences. Codon positions included were $1 \mathrm{st}+2 \mathrm{nd}+3 \mathrm{rd}+$ Noncoding. There were a total of 1182 positions in the final dataset. Evolutionary analyses were conducted in MEGA X (Kumar et al. 2018). Culture accession and deposition number is 4272, while Genebank accession no. MH352480.

Tajima's neutrality test is a population genetic evolution test (Table 4) that shows whether the genes are evolving randomly (Naturally) or non-randomly. The randomly evolving DNA sequences have mutations with no effect on the health and survival of the organism

Journal of Experimental Biology and Agricultural Sciences http://www.jebas.org 

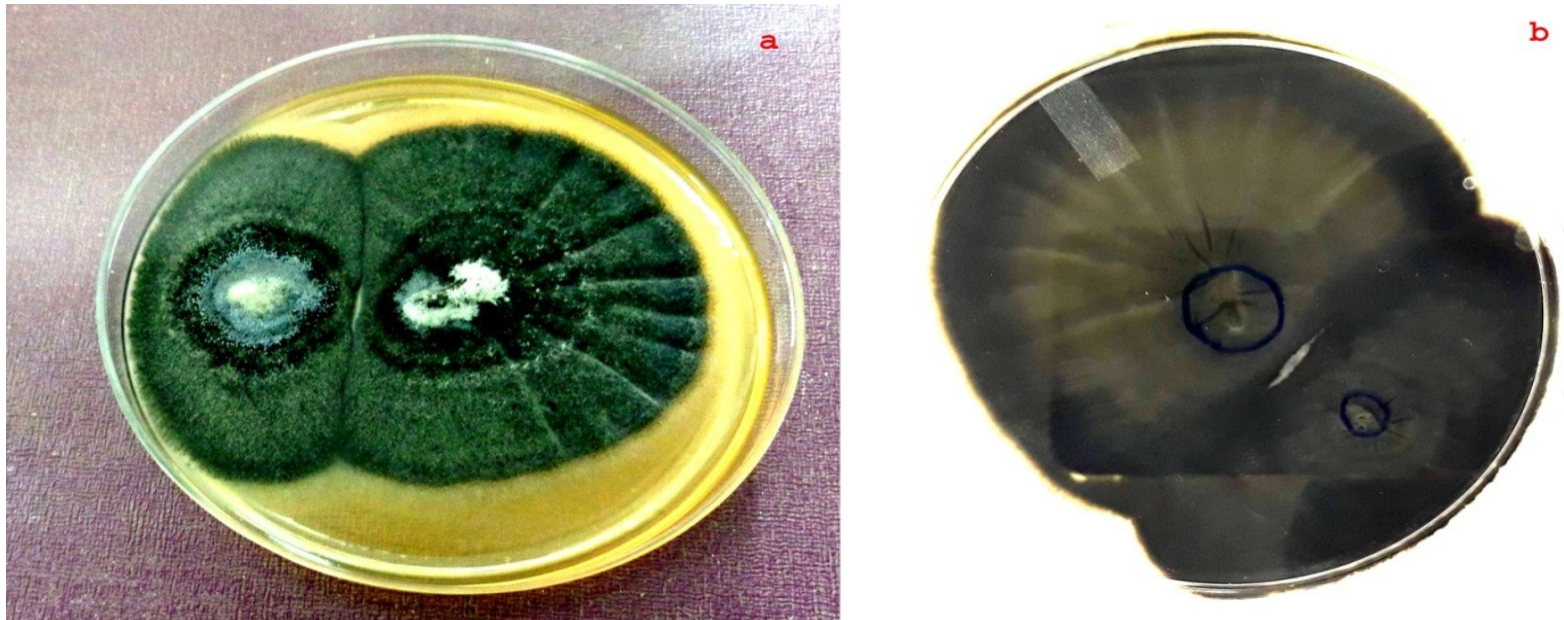

Figure 5 Photographs showing a- front view, b- reverse view of the colony of Colletotrichum fusiforme Jayawardena, Bhat, N. Tangthir, K.D.Hyde.

Table 3 Top five hits upon BLASTn analysis

\begin{tabular}{|ccccccc|}
\hline $\begin{array}{c}\text { Gene Bank } \\
\text { Accession No. }\end{array}$ & Description & Max score & $\begin{array}{c}\text { Query } \\
\text { cover }\end{array}$ & $\begin{array}{c}\text { Query } \\
\text { coverage }\end{array}$ & E value & Identity (\%) \\
\hline NR_138010.1 & Colletotrichum fusiforme & 868 & 868 & $100 \%$ & 0.0 & $100 \%$ \\
\hline KX816018.1 & Fungal endophyte isolate LIES529 & 868 & 868 & $100 \%$ & 0.0 & $100 \%$ \\
\hline HQ130691.1 & Colletotrichum sp. WF134 & 868 & 868 & $100 \%$ & 0.0 & $100 \%$ \\
\hline HQ130674.1 & Colletotrichum sp. WF115 & 868 & 868 & $100 \%$ & 0.0 & $100 \%$ \\
\hline DQ463363.1 & Colletotrichum sp. VNCF2 & 868 & 868 & $100 \%$ & 0.0 & $100 \%$ \\
\hline
\end{tabular}

Table 4 Tajima's Neutrality Test

\begin{tabular}{|cccccc|}
\hline$m$ & $S$ & $p_{\mathrm{s}}$ & $\Theta$ & $\pi$ & $D$ \\
\hline 6 & 186 & 0.157360 & 0.068917 & 0.050987 & -1.688390 \\
\hline
\end{tabular}

here $m=$ number of sequences; $n=$ total number of sites; $S=$ Number of segregating sites; $p_{\mathrm{s}}=S / n ; \Theta=p_{\mathrm{s}} / \mathrm{a}_{1} ; \pi=$ nucleotide diversity; and $D$ is the Tajima test statistic (Tajima, 1989).

while the DNA sequences evolving by non-random process having mutations that have an impact on the health and survival of the organisms then, in this case, natural selection process occurs. When Tajima's $\mathrm{D}=0$, it indicates that observed variation in the organism is similar to the expected variation and population of the organism evolving as per mutation-drift equilibrium. No natural selection observed here. When Tajima's $\mathrm{D}<0$ then negative Tajima's D signifies an excess of a low frequency of polymorphic organisms after a bottleneck or a selective sweep, indicating homozygous population size expansion. Tajima's $\mathrm{D}>0$ the positive value of Tajima's D signifies a high frequency of polymorphic organisms, indicating a decrease in population size and/or balancing selection. In the current study, the value of Tajima's D is negative which indicates the increase in the homozygous population size (Figure 6).
3.4 Classification: Based on morphological, molecular and genetic characteristics, the fungal parasite isolated from the infected $M$. ferrea leaves was identified as Colletotrichum fusiforme and detail classification of this is as follows:

Kingdom: Fungi

Division: Ascomycota

Class: Sordariomycetes

Order: Phyllachorales

Family: Phyllachoraceae

Genus: Colletotrichum

Species: fusiforme 


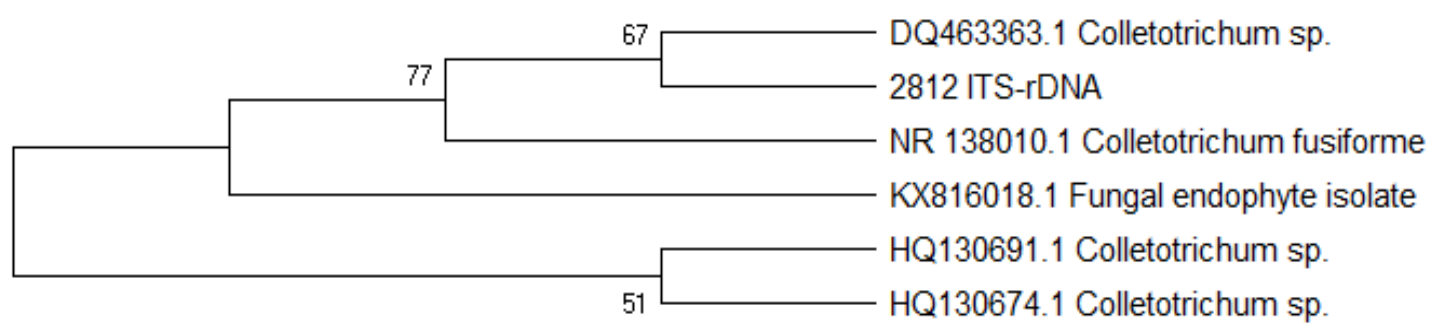

Figure 6 Evolutionary analysis by Maximum Likelihood method

\section{Discussion}

The isolated ITS sequence show 100 per cent sequence similarity with $C$. fusiforme (Altschul et al., 1990) and clusters with the $C$. fusiforme with 77 per cent bootstrap value in the phylogram generated with Maximum Likelihood Method using MEGA-X (Tamura \& Nei 1993). Tajima's D test gives the negative value which indicates the increase in the homozygous population size. Morphologically the isolate showing great similarity with $C$. fusiforme in its dimensions of setae, conidia but at the same time the isolate show some differences in some of the characters such as setae (aseptate) and conidia (only smooth-walled and egutulate). The detailed phylogenetic analysis on morphological as well as a molecular basis, the isolate was identified as Colletotrichum fusiforme Jayawardena, Bhat, N. Tangthir, K.D.Hyde. The available mycological literature revealed that this is the first record from India and the first report on the host M. ferrea (Index fungorum website on June 2020).

\section{Acknowledgement}

The authors are grateful to the Head, Department of Botany, Dr Harisingh Gour University Sagar, M.P. for providing necessary facilities and authors are also grateful to the curator, AMH Pune, Maharashtra, India for deposition of the sample and providing accession no.

\section{Conflict of interest}

The authors declare that they have no conflict of interest

\section{References}

Altschul SF, Gish W, Miller W, Myers EW, Lipman DJ (1990) Basic local alignment search tool. Journal of Molecular Biology 215:403-410. DOI: 10.1016/S0022-2836(05)80360-2.

Ariyawansa HA, Hyde KD, Jayasiri SC, Buyck B, Thilini Chethana KW, Dai DQ, Dai YC, Daranagama DA, Jayawardena RS, Lücking R, Ghobad-Nejhad M, et al. (2015) Fungal diversity notes 111-252taxonomic and phylogenetic contributions to fungal taxa. Fungal Diversity 75: 27-274. https://doi.org/10.1007/s13225-015-0346-5
Asif M, Jafari SF, Iqbal Z, Revadigar V, Oon CE, Majid ASA, Majid AMSA (2017) Ethnobotanical and Phytopharmacological attributes of Mesua ferrea: A mini review. Journal of Applied Pharmaceutical Science 7: 242-251.

Cannon PF, Damm U, Johnston PR, Weir BS (2012) Colletotrichum - current status and future directions. P. Studies in Mycology 73: 181-213.

Carlier G, Lorand JP, Bonhomme M, Carlotto V (1996) A reappraisal of the Cenozoic inner arc magmatism in southern Peru: consequences for the evolution of the Central Andes for the past 50 ma. Third ISAG St Malo, France, extended abstracts, Pp 551-554

Chahar M, Kumar DS, Lokesh T, Manohara K (2012) In-vivo antioxidant and immunomodulatory activity of mesuol isolated from $M$. ferrea seed oil. International Immunopharmacology 13:386-91.

Corda ACI (1831) Die Pilze Deutschlands. In: Sturm J (Ed.) Deutschlands Flora in Abbildungen nach der Natur mit Beschreibungen . Sturm, Nürnberg: vol. 3, Abt. 12: 33-64, tab. 21-32.

Dean R, Van Kan JA, Pretorius ZA, Hammond-Kosack KE, Di Pietro A, Spanu PD, Rudd JJ, Dickman M, Kahmann R, Ellis J, Foster GD (2012) The Top 10 fungal pathogens in molecular plant pathology. Molecular Plant Pathology 13: 414-430.

Edgar RC (2004) MUSCLE: multiple sequence alignment with high accuracy. Nucleic Acids Research 32: 1792-1797

Farr DF, Aime MC, Rossman AY, Palm ME (2006) Species of Colletotrichum on Agavaceae. Mycological Research 110: 1395-1408.

Felsenstein J (1985) Confidence limits on phylogenies: An approach using the bootstrap. Evolution 39:783-791.

Felsenstein J (2004) Inferring phylogenies. Sunderland (MA): Sinauer Associates.

Hall BG (2011) Phylogenetic trees made easy: a how-to manual. 4th ed. Sunderland (MA): Sinauer Associates. 
Hall BG (2013) Building Phylogenetic Trees from Molecular Data with MEGA. Molecular Biology and Evolution 30(5):1229-1235

Hall JL, Hawes CH (1991) Electron microscopy of plant cells. Academic Press, New York

Hawksworth DL (1974) Mycologist's handbook. Commonwealth Mycological Institute, Kew, Surrey, U.K. Pp 13-18

Jayawardena RS, Hyde KD, Jeewon R, Li XH, Liu M, Yan JY (2016) Mycosphere Essay 6: Why is it important to correctly name Colletotrichum species? Mycosphere.

Joseph C, Ilanchezhian R, Biswajyoti P, Harish C (2010) Pharmacognostical study of nagakeshara (M. ferrea) - an ingredient in Vyaghrihareetaki Avaleha. International Journal of Research in Ayurveda and Pharmacy 1:264-272.

Keawsa-ard S, Liawruangrath B, Kongtaweelert S (2015) Bioactive Compounds from Mesua ferrea Stems. Chiang Mai Journal of Science 42:185-95.

Kumar GA (2014) Colletotrichum gloeosporioides: Biology, Pathogenicity, and Management in India. Journal of Plant Physiology \& Pathology 2:2.

Kumar S, Stecher G, Li M, Knyaz C, Tamura K (2018) MEGA X: Molecular Evolutionary Genetics Analysis across computing platforms. Molecular Biology and Evolution 35:1547-1549.

Lim TK (2012). Edible medicinal and non-medicinal plants. New York: Springer.

Mall TP, Kumar A (2014) Foliicolous fungi: Earths Living Wealth from Shrawasti (Uttar Pradesh), India. International Journal of Interdisciplinary and Multidisciplinary Studies 1: 61-70.

Mills PR, Hodson A, Brown AE (1992) Molecular differentiation of Colletotrichum gloeosporioides isolates infecting tropical fruits. In: Bailey JA, Jeger MJ (Eds.), Colletotrichum: Biology, Pathology and Control CABI, Wallingford, UK: 269-288.

Nei M, Kumar S (2000) Molecular evolution and phylogenetics. New York: Oxford University Press.
Purkayastha RP, Sen Gupta M (1973) Studies on conidial germination and appressoria formation in Colletotrichum gloeosporioides Penz. Causing anthracnose of jute (Corchorus olitorius L.). Zeitschrift fur Pflanzenkrankheiten und Pflanzenschutz 80: 718-724.

Rahman SMM, Shabnom S, Quader MA, Hossain MA (2008) Phytochemical study on the ethylacetate extract of the leaves of Mesua ferrea Linn. Indonesian Journal of Chemistry 8:242-44.

Sabeena A, Hosagoudar VB, Divaharan V (2018) Foliicolous fungi on medicinal plants in Thiruvananthapuram District, Kerala, India. Journal of Threatened Taxa 10: 11470-11479.

Savile DBO (1962) Collection and care of Botanical specimens. Canada Department of Agriculture Publication Research Branch 1113.pp. 124

Sreenivasaprasad S, Brown AE, Mills PR (1992) DNA sequence variation and interrelationship among Colletotrichum species causing strawberry anthracnose. Physiological and Molecular Plant Pathology 41: 265-281.

Sunkar S, Sibitha V, Valli Nachiyar C, Prakash P, Renugadevi K (2017) Bioprospecting endophytic fungus Colletotrichum sp. isolated from Artocarpus heterophyllus for anticancer activity. Research Journal of Biotechnology 12: 46-56.

Sutton BC (1980) The Coelomycete. Fungi Imperfecti with pycnidia, acerveuli and stromata. C.M.I. Kew England.

Tajima F (1989) Statistical methods to test for nucleotide mutation hypothesis by DNA polymorphism. Genetics 123:585-595.

Tamura K, Nei M (1993) Estimation of the number of nucleotide substitutions in the control region of mitochondrial DNA in humans and chimpanzees. Molecular Biology and Evolution 10:512-526.

Tode HJ (1790) Fungi Mecklenbergensis Selecti 1: 1- 64.

White T, Bruns T, Lee S, Taylor J (1990) Amplification and Direct Sequencing of Fungal Ribosomal Rna Genes For Phylogenetics. PCR Protocols: A Guide to Methods And Applications. Academic Press; Pp. 315-322. 